\title{
SHAKESPEAREAN TRAGEDY
}




\title{
SHAKESPEAREAN TRAGEDY
}

\author{
LECTURES ON \\ HAMLET, OTHELLO , KING LEAR \\ MACBETH
}

A. C. BRADLEY, LL.D., Litt.D.

Sometime Professor of Poetry in the University of Oxford

Introduction to the Third Edition

JOHN RUSSELL BROWN

Macmillan Education 


\section{ISBN 978-0-333-57536-9 ISBN 978-1-349-22059-5 (eBook) \\ DOI 10.1007/978-1-349-22059-5}

Introduction to the Third Edition @ John Russell Brown 1992

Softcover reprint of the hardcover 3rd edition 1992

All rights reserved. For information, write:

Scholarly and Reference Division,

St. Martin's Press, Inc., 175 Fifth Avenue, New York, N.Y. 10010

First published in the United States of America in 1957

Reprinted 1957, 1959, 1961, 1962, 1963, 1964

ISBN 978-0-312-07923-9 (cloth) ISBN 978-0-312-07922-2 (paperback)

Library of Congress Cataloging-in-Publication Data Bradley, A. C. (Andrew Cecil), 1851-1935

Shakespearean tragedy: lectures on Hamlet, Othello, King Lear, Macbeth/A. C. Bradley; introduction to the third edition by John Russell Brown.-3rd ed.

p. $\mathrm{cm}$.

Includes index.

ISBN 978-0-312-07923-9 (cloth).-ISBN 978-0-312-07922-2 (pbk.)

1. Shakespeare, William, 1564-1616-Tragedies. 2. Tragedy.

I. Title.

PR2983.B7 1992

822.3'3-dc20 
To

MY STUDENTS 


\section{PREFACE}

These lectures are based on a selection from materials used in teaching at Liverpool, Glasgow, and Oxford; and I have for the most part preserved the lecture form. The point of view taken in them is explained in the Introduction. I should, of course, wish them to be read in their order, and a knowledge of the first two is assumed in the remainder; but readers who may prefer to enter at once on the discussion of the several plays can do so by beginning at page 70 .

Any one who writes on Shakespeare must owe much to his predecessors. Where I was conscious of a particular obligation, I have acknowledged it; but most of my reading of Shakespearean criticism was done many years ago, and I can only hope that I have not often reproduced as my own what belongs to another.

Many of the Notes will be of interest only to scholars, who may find, I hope, something new in them.

I have quoted, as a rule, from the Globe edition, and have referred always to its numeration of acts, scenes, and lines.

November, 1904. 


\section{NOTE TO SECOND AND SUBSEQUENT IMPRESSIONS}

In these impressions I have confined myself to making some formal improvements, correcting indubitable mistakes, and indicating here and there my desire to modify or develop at some future time statements which seem to me doubtful or open to misunderstanding. The changes, where it seemed desirable, are shown by the inclusion of sentences in square brackets. 


\section{CONTENTS}

InTRODUCTION TO THE THIRd EDITION

by John Russell Brown

xiii

INTRODUCTION

XXXV

LECTURE I

The Substance of Shakespearean Tragedy

LECTURE II

Construction in Shakespeare's Tragedies

LECTURE III

Shakespeare's Tragic Period - Hamlet

LECTURE IV

HAMLET

LECTURE V

OTHELLO

LECTURE VI

OTHELlo

LECTURE VII

KING LEAR

LECTURE VIII

KING LEAR

LECTURE IX

MACBETH

LECTURE X

MacbeTH 
Note A. Events before the opening of the action in Hamlet

Note B. Where was Hamlet at the time of his father's death?

Note C. Hamlet's age

Note D. 'My tables - meet it is I set it down'

Note E. The Ghost in the cellarage

Note F. The Player's speech in Hamlet

Note G. Hamlet's apology to Laertes

Note H. The exchange of rapiers

Note I. The duration of the action in Othello

Note J. The 'additions' to Othello in the First Folio. The Pontic Sea

Note K. Othello's courtship

Note L. Othello in the Temptation scene

Note M. Questions as to Othello, Iv. i

Note N. Two passages in the last scene of Othello

Note O. Othello on Desdemona's last words

Note P. Did Emilia suspect Iago?

Note Q. Iago's suspicion regarding Cassio and Emilia

Note R. Reminiscences of Othello in King Lear 
Note S. King Lear and Timon of Athens

Note T. Did Shakespeare shorten King Lear?

Note U. Movements of the dramatis persona in King Lear, II

Note V. Suspected interpolations in King Lear

Note W. The staging of the scene of Lear's reunion with Cordelia

Note X. The Battle in King Lear

Note Y. Some difficult passages in King Lear

Note Z. Suspected interpolations in Macbeth

Note AA. Has Macbeth been abridged?

Note BB. The date of Macbeth. Metrical Tests

Note CC. When was the murder of Duncan first plotted?

Note DD. Did Lady Macbeth really faint?

Note EE. Duration of the action in Macbeth.

Macbeth's age. 'He has no children'

Note FF. The Ghost of Banquo 


\title{
INTRODUCTION TO THE THIRD EDITION
}

\author{
by JOHN RuSSELl BROwN
}

Andrew Bradley was a pioneer, and he struck gold. In his Shakespearean Tragedy, first published in 1904, he not only tackled problems which other critics had avoided, but was bold enough to set out to discover the 'usual plan' on which Shakespeare based his most amazing plays. He sought the reasons why the tragic heroes acted as they did and not otherwise, searching for underlying motives and trying to follow the course of their passions. He wanted to understand what the plays 'did' as well as what they 'said', and so kept the reaction of audiences within the range of his study. His book is a collection of ten spirited lectures, carefully revised, and it is still, at the end of the century, an essential landmark in the endless and often confusing terrain of Shakespearean criticism and scholarship. A reader is drawn willingly into the author's mind as he explores the plays. Rarely is Andrew Bradley dogmatic, because he proceeded by raising questions and doubting his own conclusions. In subsequent editions, he supplied corrections to earlier judgments and added new comments or lengthy footnotes - after one of these he was later to confess, 'I wish to withdraw the whole note', but left his earlier thoughts in place so that his readers would be encouraged to think through the problems for themselves. If such a book were published today, its author would be praised as an adventurer for whom knowledge was not fixed but always in process, who sought an ordered coherence but was committed to distrust and dissatisfaction, who tested each hypothesis and guaranteed no more than an encounter with Shakespeare's text that was aware of the requirements of theatre practice and the differing responses of reader, actor and audience.

Bradley paid brief respect to Aristotle at the beginning of his book, but he was more attuned to Socrates than to any 
prescriptive or classifying thinker. He distanced himself just as firmly from Hegel's view of tragedy, which was then a popular model for criticism; he did not deal in general issues of a conflict of good and evil, or with its resolution, but stepped around these problems by asking, 'Who are the combatants in this conflict?' What happens in a play and how do we react were the questions on which Bradley focused constantly and persistently; and he did not let them rest, even while he proposed ways in which they might be answered with some consistency and assurance.

But in his own day Bradley was hailed as a reliable authority. He had outpaced his rivals with such apparent ease that critics did not notice his distinctive insecurity and independence of mind. In 1904, the year the book was published, The Spectator declared: 'We have no hesitation in putting Professor Bradley's book far above any modern Shakespearean criticism that we know, worthy to rank very near the immortal work of Lamb and Coleridge.' A decade later, in 1916, Professor D. Nichol Smith's introduction to three centuries of Shakespeare criticism placed the book firmly by relating it to the past:

Mr Bradley's penetrative analysis of the four chief tragedies is the last great representative of nineteenth-century criticism, and nothing better in its kind need be expected. It continues the traditions inaugurated by Whately and Morgann, and established by Coleridge and Hazlitt.

(Shakespeare Criticism, p. xxi)

Although Bradley had cast his book in the form of an active dispute, it was received with greater confidence than it was offered. Its innovations seemed only to underline what had been written previously or to make eminently good sense about those mysterious qualities in Shakespeare's plays which Maurice Morgann, writing in 1777, had been content to call 'poetic magic'.

On the other hand, no one could call Shakespearean Tragedy a revolutionary manifesto or a work that drew attention to its 
own originality. Bradley was not attempting to sail over strange seas of thought entirely without other voices to guide him or some fixed marks towards which to direct his course. Certain preconceptions and preoccupations he did bring with him and it was because these were so in tune with the spirit of the times that his book appeared less original than it was.

Like many of his contemporaries, Bradley was obsessed by an ideal of 'greatness'. His first 'lecture', 'The Substance of Shakespearean Tragedy', sets this forth:

His tragic characters are made of the stuff we find within ourselves and within the persons who surround them. But, by an intensification of the life which they share with others, they are raised above them; and the greatest are raised so far that, if we fully realise all that is implied in their words and actions, we become conscious that in real life we have known scarcely any one resembling them. Some, like Hamlet and Cleopatra, have genius. Others, like Othello, Lear, Macbeth, Coriolanus, are built on the grand scale; and desire, passion, or will attains in them a terrible force.

This show of greatness is more fundamental to Shakespeare's purposes, as perceived by Bradley, than any moral superiority or wisdom:

The tragic hero with Shakespeare ... need not be 'good', though generally he is 'good' and therefore at once wins sympathy in his error. But it is necessary that he should have so much of greatness that in his error and fall we may be vividly conscious of the possibilities of human nature. Hence, in the first place, a Shakespearean tragedy is never, like some miscalled tragedies, depressing. No one ever closes the book with the feeling that man is a poor mean creature. He may be wretched and he may be awful, but he is not small.

Bradley defined this 'greatness' in many ways: it is strength of will, power of life, glory, magnificence, magnitude. The hero is 'grand', 'beautiful', 'heroic', 'colossal', 'supreme'; he is 
said to be 'holding a volume of force which in repose ensures pre-eminence without an effort'. All of them 'command' our respect and 'compel' our attention. While recognizing the enormity of Macbeth's crimes, and those of his Lady, Bradley concluded nevertheless that these characters were 'sublime' - a word that is never used by Shakespeare of a human being and had to wait for Milton and mid-seventeenth-century preachers to achieve any currency, before it later became one of the shibboleths of the romantic age.

For Bradley, Shakespeare's tragic heroes were persons of mysterious and superior powers, and this greatness always triumphed. While recognizing a loss of power in Lear, Bradley still held his ground:

we feel also that everything external has become nothingness to him, and that what remains is 'the thing itself', the soul in its bare greatness.

Viewed in this way, Shakespeare's tragedies become plays about exceptional individuals who are of more significance than the society in which they live, whose sublimity beggars the critic of means to define it closely.

Readers who are not reassured by the thought that one man or woman can transcend all other human beings will find the direction of Bradley's discourse to be perverse and, possibly, irritating. It was, indeed, more appropriate to an age in which many people believed that a strong, just, and gifted hero - a superman - could right the wrongs of the world and ameliorate its suffering. Preoccupation with individual greatness and power, or with sublimity of mind, at the cost of attention to social and corporate good, has removed many books from effective critical debate long before the end of the twentieth century. That Bradley's Shakespearean Tragedy has kept in continuous use from its first publication to the present day is due as much to the exceptional lucidity of its exposition as to its author's detailed knowledge of the plays. Readers can sense that Bradley lived with the problems he encountered, and are able to share the experience which this adventure entailed. Besides, his less trammelled specula- 
tions derive from a deeper agnosticism which is much more in keeping with current thought.

In a large measure, Bradley was an honest thinker and his book never tries to coerce its readers. He did, on occasion, assert that critics holding opposite opinions were 'untrue to Shakespeare's mind', but his meticulous knowledge of the text gave him more right to such assertions than others. Besides he proceeded then by asking another question, and his own opinion was offered with hesitation:

What then is this feeling, and whence does it come? I believe that we shall find that it is a feeling not confined to King Lear, but present at the close of other tragedies. . .

After more discussion, he referred only to 'the feeling which I have tried to describe' and to 'some such idea' as he had adumbrated. He was not content to quote one piece of dialogue against another, but wrestled with what the play does for an audience, not with what various characters say. Because he encouraged readers to think for themselves, debate with this author is invigorating; he directs attention to implications and practicalities that might escape the most patient scrutiny of words alone, and he seems, sometimes, to stand stock still so that we can listen for new clues, just as he had done.

Bradley's predilections led him to study the conscious being of each leading character as displayed progressively to an audience in performance. Because this consciousness is a major element of the theatrical life of the tragedies, his explorations are of lasting benefit to all readers, whatever the interest of his conclusions. He has shown how

Shakespeare has concentrated attention on the obscurer regions of man's being, on phenomena which make it seem that he is in the power of secret forces lurking below, and independent of his consciousness and will.

Bradley can teach us how to read a dramatic text dramatically. He was drawn to 'look below the surface' to discover 
'evidence' which can then be related to all other kinds of evidence that have been gathered from the words that are spoken. He noted, for example, 'an almost unendurable impatience' that was expressed chiefly in the rhythms of the lines. He argued that, while a reader may be hasty or over ingenious, actors 'have to ask themselves what was the precise state of mind expressed by the words they have to repeat'. So Iago must be heard knowing that he lies: 'one must constantly remember not to believe a syllable that Iago utters on any subject, including himself, until one has tested his statement':

In the second soliloquy he declares that he quite believes Cassio to be in love with Desdemona: it is obvious that he believes no such thing, for he never alludes to the idea again, and within a few hours describes Cassio in soliloquy as an honest fool. This final reason for ill-will to Cassio never appears till the Fifth Act.

Like Hamlet, Iago is moved by forces which he does not understand, and the actor and careful reader should search them out.

Such an emphasis on the inner workings of a mind and on pressures of which the conscious mind is ignorant was very much in tune with a new 'scientific' interest in psychology, but Bradley makes no mention of Sigmund Freud, whose Psychopathology of Everyday Life was published in the very same year as his investigations into the subconscious of Shakespeare's heroes. Nor does he allude to Anton Chekhov, who died that same year after completing the plays that did more than any others to encourage actors to play the 'subtext' of their roles and rely on the 'hidden' pressures within a scene.

Bradley focused his lectures on Shakespeare's heroes and the qualities that made them 'great', and for this his book is chiefly remembered. But he was also preoccupied with another inquiry: he wanted to know how the events of the tragedies were controlled, why one 'force' prevailed over 
another. Did Shakespeare make the hero responsible for his own fate, either consciously or unconsciously? Did he contrive a 'poetic justice' which distributed rewards appropriate to each deed, both good and evil? Did 'Providence' or supernatural powers exercise ultimate sanctions? What could withstand destructive violence? Such questions led Bradley to look beyond the characters and search for the decisive moments in a play's action. From this enquiry he sought to enunciate ideas which are only implicit in the play's dialogue and yet shape its action and influence the audience's reaction.

These problems are approached resolutely in the very first lecture and are given prominence at the conclusion of the study of each play. Bradley judged that irrational forces were not important: although the leading characters are prey to insanity, somnambulism and hallucinations, they remain responsible and are never 'really mad'. Similarly, the supernatural powers are never the 'sole motive force: . . . so far indeed are we from feeling this, that many readers run to the opposite extreme, and openly or privately, regard the supernatural as having nothing to do with the real interest of the play'. Bradley also argued that accident had small influence: 'almost all the prominent accidents occur when the action is well advanced and the impression of the causal sequence is too firmly fixed to be impaired'. The dominant factor in the action of all these tragedies lies, rather, in 'deeds which issue from character'.

These judgments are established at the outset and reconsidered throughout the book. By the end of the first lecture, he was already more forthright about the supernatural: the dramatis persone 'may speak of gods or of God, of evil spirits or of Satan, of heaven and of hell, ... . [but] these ideas do not materially influence [Shakespeare's] representation of life, nor are they used to throw light on the mystery of its tragedy'. On the other hand, Hamlet suggested to Bradley that there is 'some vaster power' behind the ordering of its action, under which control the hero's death is accomplished:

we do not define it, or even name it, or perhaps even say to ourselves that it is there; but our imagination is haunted by 
the sense of it, as it works its way through the deeds or the delays of men to its inevitable end.

In King Lear, Bradley pointed to four distinct theories about the nature of the 'ruling power' in life which are given verbal definition in the text, and then he argued his own way towards a different judgment implied in the play's action: 'Good, in the widest sense, seems thus to be the principle of life and health in the world; evil, at least in these worst forms, to be a poison'. For him the image of Cordelia, 'calm and bright and still', holds the centre of Shakespeare's design, although in the last events she is 'detached in a manner from the action of the drama'. The 'gods' do not 'defend' Cordelia, as Albany prays they should, but 'extreme evil cannot long endure' while 'all that endures the storm is good, if not great'.

In all four tragedies, Bradley discovered, by implication and through his own imaginative brooding on their action, an image of 'a world travailing for perfection'. No god protects men and women or rewards them according to their good and evil deeds, but there was a bias towards good in the way human actions work together in the face of catastrophe.

Attempting to view each play as a complete action and to seek for organizing principles, Bradley was often led to reappraise individual incidents. For instance, noting that the Porter in Macbeth 'does not make me smile', he argued that 'that is what Shakespeare intended, and ... he despised the groundlings if they laughed'. Other critics had advanced good reasons for the scene's authenticity, but Bradley added a defence of its uncertain tone, which served, he thought, to heighten the play's terror. He also anticipated many later critics by taking a play's 'atmosphere' into account. This was created, he wrote, 'by a multitude of small touches, which at the moment may be little noticed but still leave their mark on the imagination'. So in Macbeth he noted the recurring darkness which Shakespeare established by many scenes set at night, by verbal images of 'thick night' and 'strangled light', by the contrast of a torch dashed out by Banquo's murderers and a candle that Lady Macbeth has by her continually at the end, by the 'brandished steel' that 'smoked with bloody 
execution' in Macbeth's hand, and above all by references to blood, most appallingly in the precise image of Lady Macbeth's 'shuddering cry, "Yet who would have thought the old man to have had so much blood in him?"' In Bradley's view, the vividness, magnitude, and violence of the imagery in this play serve to keep the audience's 'imagination moving on a "wild and violent sea", while it is scarcely for a moment permitted to dwell on thoughts of peace and beauty'.

Fortunately Bradley's preoccupations did not quench the vitality of his engagement with Shakespeare's texts, but seem rather to have whetted the sharpness of his mind. In his Introduction, he praised the 'habit of reading with an eager mind', which made 'many an unscholarly lover of Shakespeare a far better critic than many a Shakespeare scholar', and his book exemplifies this eagerness. Such readers approach a play open-eyed, 'more or less as if they were actors who had to study all the parts' and 'want to realise fully and exactly the inner movements which produced these words and no other, these deeds and no other, at each particular moment'. Allied with Bradley's great knowledge and his concern for the whole of a dramatic action, this approach is exploratory, invigorating, and based solidly in dramatic encounter - what happens on a stage and in an audience's reaction to it.

An instructive example of Bradley's concern for the effect of a play as a whole is the warning at the end of the first lecture on King Lear that his argument has so far emphasized 'only certain aspects of the play and certain elements in the total impression; and in that impression the effect of these aspects, though far from being lost, is modified by that of others'. Living 'impressions' and 'effects' are vital to Bradley's experiential approach to Shakespeare's text:

I will ask the reader to notice that the passage from Lear's entrance with the body of Cordelia to the stage-direction He dies (which probably comes a few lines too soon) is 54 lines in length, and that 30 of them represent the interval during which he has absolutely forgotten Cordelia. . . . To make Lear during this interval turn continually in anguish 
to the corpse, is to act the passage in a manner irreconcilable with the text, and insufferable in its effect. I speak from experience. I have seen the passage acted thus, and my sympathies were so exhausted long before Lear's death that his last speech . . . left me disappointed and weary.

Shakespeare's plays are studied today in many ways of which Bradley could have had no knowledge. He did not see that the tragedies present carefully delineated societies, as well as heroes and other interesting individuals. Political issues did not register clearly for him and so, for example, distinctions among the minor characters of Macbeth and Hamlet escaped his notice, and he argued that King Lear is 'overloaded' with secondary characters and unnecessary events. He often missed the effect of groupings and movements on stage which display changes in authority and allegiance, and also the political cunning which informs apparently casual exchanges. Neither his contemporary political awareness nor his study of Elizabethan and Jacobean society was sufficient to reveal how many of Shakespeare's characters are held together, or divided in significantly different ways, by authority, power, family interests, age, wealth, poverty, ignorance or knowledge. In two lectures on Othello, Bradley argued that Othello's race and background were not important elements in the play - 'I could as easily believe that Chaucer meant the Wife of Bath for a study of the peculiarities of Somerset' - and he almost passed over Emilia's declaration of women's rights, exceptional though that was in Shakespeare's age and placed climactically in the presentation of Desdemona. The distinction between a commissioned and non-commissioned officer in a Renaissance army, between an 'Ancient' and a 'Lieutenant', does not enter his careful discussion of Othello's preferment of Cassio rather than Iago. None of this held as much interest for him as the character's minds, passions, and 'souls', considered as representative of 'human nature', or as the consequences of their actions towards each other. In so far as their leading characters are motivated by fear, hope, desire, 
hatred, certainty and, especially perhaps, uncertainty, Bradley had thought long and hard about the plays; and there was matter enough here to fill his book to overflowing.

Nor was Bradley very well read in the drama of Shakespeare's age, so that he could not be a reliable guide to the variety of theatrical style in the plays. He was highly sensitive to verbal style, but did not give much attention to changes in theatrical convention within a play, or even within a single scene, when dramatic illusion shifts from subtle portrayal of individual consciousness to social rituals and demonstrations, or to serious games, chases, debates, trials and other corporate actions, or from lyric and sensitive speech to expository or satiric performance. This may be one reason why he gave little account of the mad scenes and supernatural appearances, why grotesque or dangerous wit was passed over, and ceremony undervalued. Bradley's Shakespeare was a dramatist who sometimes slipped into crude dramaturgy or bombastic utterance, but who sought to provide scenes of personal encounter that achieved high intensity or sustained composure - modes of theatre which encouraged an audience to respond with careful thought. Progress through the plays was a pursuit of wisdom about the nature of mankind.

There are some brief references to Marlowe, Jonson, Middleton, Marston, Heywood, Greene and Peele, but mostly for incidental matters of verbal style. Bradley's main source of dramatic understanding was the Greek tragedians - he had been Chorus Master for a production of the Agamemnon while teaching at Balliol College, Oxford, in 1880 - and his treatment of the structure of Shakespeare's plays is illuminated on several occasions by reference to Aeschylus and Sophocles. It was the width and not the specialization of this critic's reading which provided the contrasts and comparisons for better appreciation of Shakespeare's purposes. So Iago is seen over against Goethe's Mephistopheles and Milton's Satan; Homer, Wordsworth, and Turgenev are at hand for debate about Shakespeare's understanding of 'man'. Arthurian legends, Old French romances and the Decameron help to make a point about the handling of narrative.

While Bradley did not busy himself with the peculiarities of 
Elizabethan dramaturgy, usually dismissing it as crude or primitive, he was very aware of dramatic effect in terms of direct representation of individual consciousness and personal encounter, and it is for this that he is still read today. For example, he wrote of Iago brooding over his actions as if Shakespeare had given him his own dramatist's awareness: 'drawing at first only an outline, puzzled how to fix more than the main idea, and gradually seeing it develop and clarify as he works upon it or lets it work.' He was adept at tracing the counterflows of thought and emotion.

Bradley was sensitive to Shakespeare's use of words without being particularly aware of Elizabethan usages. When his book was published, the New English Dictionary on Historical Principles had reached only volume V $(\mathrm{H}-\mathrm{K})$, less than half way through its protracted compilation and printing at the Oxford University Press. Bradley understood very well the distinctions between familiar and more sophisticated styles, but could not recognize proverbial usages or the marks of class and rank. He was responsive to the resonance, association and ambiguities of words, but specialist usages appropriate to law, finance, warfare, domestic or courtly life often escaped his attention. In particular, sexual references frequently eluded him: he acknowledged frankly that 'I am unable to arrive at a conviction as to the meaning' of much that Hamlet says to Ophelia, and he offered the reader little further help. Of Lady Macbeth, he wrote that there is 'not the faintest trace' that her 'hold upon her husband lay in seductive attractions deliberately exercised'.

But in editorial and textual matters Bradley's Shakespearean Tragedy is more in tune with present-day thinking than many books published before the mid-1980s. By that time, a number of studies - by Ernst Honigmann, Peter Blaney, Paul Werstein, and Steven Urkowitz, by the New Oxford editors, and by others - had thoroughly unsettled older assumptions that each of Shakespeare's plays had existed in a single authoritative text and that an editor's task was to get as close as possible to that 'definitive' original. Perhaps Bradley was especially aware of questions of textual authority because as a young man he had confronted and rejected the dogmatic 
certainties of his father who was a well-known fundamentalist preacher. Certainly a reader of his account of the four tragedies is invited repeatedly to consider rival readings from Quarto and Folio. He debated about a rewriting of Macbeth to account for some features of the sole Folio text. With both King Lear and Othello, it seems at times as if he welcomed the variant readings as a means of probing deeper into the workings of Shakespeare's creative mind and maintaining his own speculative approach to understanding. In a long note, he discussed passages in the Folio Othello which are missing in the Quarto and was very prepared to conclude that 'these two texts are distinct versions of the play'. Bradley's respect for the Quarto of Lear gave rise to interesting reflections: for the last moments of Lear, the Quarto's 'O, O, O, O.' is given some consideration, while he was decisively against its reduction of the Folio's four 'never's to three - although 'all the actors I have heard have preferred this easier task'. In an extended note on the scene of Lear's reunion with Cordelia, he explored his dissatisfaction with the stage directions in both texts, and offered his own solution. He chose Cordelia's

I am sure my love's

More ponderous than my tongue.

(I. i. $76-7$ )

from the Folio, against the first Cambridge editor's preference for the Quarto's 'more richer', defending his reading on the grounds that the phrase sounded like 'the author's improvement of a phrase that he thought a little flat'. For Bradley, King Lear was available in two versions, both representing Shakespeare's play.

In his discussion of Hamlet, Bradley was less ready to give the Folio and the 'good' second Quarto separate status and appealed less frequently to their different readings. The Folio's omission of the soliloquy in IV. iv, 'How all occasions do inform against me ...', is given due notice and even such a small matter as its omission of an inarticulate cry for Ophelia in IV. v, but the good Quarto's omission of Hamlet calling on his mother before he enters her closet (III. iv) and of his 
leaping into Ophelia's grave (v. i. 243) he did not mention, the authority of these details being taken for granted. Any careful student of the four major Shakespearean tragedies needs to be alert to the existence of alternative texts at all times, and Bradley's concern for these matters, although useful, does not absolve him or her of this responsibility; it does, however, keep the issues more in focus than many later studies which pay them little or no regard.

The respect in which Bradley may seem to stand at greatest distance from the present is in his assumption that art seeks necessarily for unity and for a resolution of differences. In looking for clues to the nature of Shakespearean tragedy, he took for granted that this would depend on a profound and single vision, developing from play to play and governing the plan of each. He wrote of this controlling principle as an 'idea' and a 'mystery', and he assumed that his task was to pluck this heart out of the texts and out of his experience of the plays in performance. Indeed his book is a record of this effort and it is therefore at odds with recent studies which give special, or 'privileged', attention to disordered and discordant elements, and to subversions of conventional resolutions. While Bradley saw Shakespeare as a highly individual author, he did not present him as one who was impelled to cause 'dislocations' and set up 'dialectical' oppositions within a play. For example, he did not highlight the role of Edmund in King Lear, as Jonathan Dollimore has done, in his Radical Tragedy (1984), so arriving at this conclusion:

The notion of man as tragic victim somehow alive and complete in death is precisely the kind of essentialist mystification which the play refuses. It offers instead a decentring of the tragic subject which in turn becomes the focus of a more general exploration of human consciousness in relation to social being - one which discloses human values to be not antecedent to, but rather informed by, material conditions. Lear actually refuses then that autonomy of value which humanist critics so often insist that it ultimately affirms. . . . 
.. . instead of complying with the demands of formal closure - the convention which would confirm the attempt at recuperation - the play concludes with two events which sabotage the prospect of both closure and recuperation.

(pp. 202-3)

The difference between these two critics, separated by eighty years in time, is that between an ideal and a realist art. Mr Dollimore had quoted the playwright, Bertolt Brecht, with approval:

The bourgeois theatre's performances always aim at smoothing over contradictions, at creating false harmony, at idealization. Conditions are reported as if they could not be otherwise; . . . if there is any development it is always steady, never by jerks; the developments always take place within a definite framework which cannot be broken through. None of this is like reality, so realistic theatre must give it up.

(Appendix to the Short Organum, Schriften 7; tr. J. Willett)

Yet Bradley was not so far apart from twentieth-century realist and deconstructive criticism as may at first appear. His own mind was basically sceptical, so that he was aware of some opposing voices within the plays which, he confessed to his readers, he could 'neither separate nor reconcile'. He resisted easy solutions, so that, while he sought a single vision, he recognized:

Shakespeare was not attempting to justify the ways of God to men, or to show the universe as a Divine Comedy. He was writing tragedy, and tragedy would not be tragedy if it were not a painful mystery. Nor can he be said even to point distinctly, like some writers of tragedy, in any direction where a solution might lie.

He also knew: 
We do not like the real Shakespeare. We like to have his language pruned and his conceptions flattened into something that suits our mouths and minds.

The form of Bradley's book meant that it finished with a second lecture on Macbeth, but it was his own choice which brought the focus to bear in the last pages on the puzzling Porter episode and on the sleep-walking of Lady Macbeth. Although he had insisted that Shakespeare's major characters are never 'really mad', he acknowledged that here there is 'no rational connection in the sequence of images and ideas':

There is, again, scarcely a sign of the exaltation of disordered imagination; we are conscious rather of an intense suffering which forces its way into light against resistance, and speaks a language for the most part strikingly bare in its diction and simple in its construction.... The soaring pride and power of Lady Macbeth's first speeches return on our memory, and the change is felt with a breathless awe. Any attempt, even by Shakespeare, to draw out the moral enfolded in this awe, would but weaken it. For the moment, too, all the language of poetry - even of Macbeth's poetry - seems to be touched with unreality, and these brief toneless sentences seem the only voice of truth.

Of course, Bradley's emphasis on 'awe', 'mystery', and human suffering is different from a modern critic's interest in social values and sharp oppositions; but his recognition of 'unreality' elsewhere, as he hears something like 'truth' in the simplest words, is evidence of a mind prepared to respond in unconventional ways and to reject easy harmonies.

Reading Bradley today is a different experience from doing so at the beginning of the century. The complacent reception accorded to him then seems to undervalue the contradictions in his book, the unresolved problems, the doubts, and the less defined but pervasive sense of dissatisfaction or unease. For all the proved durability of his book, its composure seems to be precarious and it comes as only a 
small surprise that except for two anthologies, Oxford Lectures on Poetry (1909) and Miscellany (1929), its author published nothing more of substance. His career had started with controversy, which brought about his departure from Balliol College, Oxford, for Professorships first at Liverpool and then at Glasgow. By 1900, at the age of forty-nine, he had taken what today would be called early retirement, only to return to Oxford the following year as Professor of Poetry. His duties in this new post were not onerous and his tenure limited, and for five years he was very productive. In 1906, however, he returned to London to live with his sister (he was unmarried), turning down the King Edward VII Chair of English at Cambridge. Some lectures and short essays followed, but from after the First World War nothing at all has survived. He died in 1935.

Bradley's Shakespearean Tragedy is not a complete guide to Shakespeare and its interpretation of the plays does not merit full acceptance. But it is pre-eminent in its field because of its author's exploratory approach, his fine understanding of the plays as texts for performance, and the clear and engaging manner in which he presented his discoveries. It merits reading and rereading. If it is a suit of clothes we would not wear today, the quality of the cloth and the workmanship has seldom been bettered; and these achievements we can readily appreciate because they never go out of fashion.

Bradley has become a critic whom his adversaries are proud to confront; he puts them on their mettle and stimulates thought. For example, J. L. Styan's far-ranging The Shakespeare Revolution (1977), which surveys the theatre practice and scholarship of the present century, consigns Bradley's 'circumstantial character analysis' to a place among outmoded forms of criticism because his 'process of re-creating Shakespeare's scenes concealed as much as it revealed'. But, elsewhere in the same book, Professor Styan acknowledges that Harley Granville-Barker, whom he praises as the champion 
of a new theatrically based criticism, was 'enamoured' of Bradley, finding that in his writing 'the plays are plays and never cease to be plays'. 'Bradley was a most enlightened critic and one hesitates to differ from him', wrote GranvilleBarker when he did demur about a 'mere dramatic technicality' - while, at the same time, accepting Bradley's distinctive account of Iago's role in Othello.

L. C. Knights was one of the first critics to attack an excessive interest in character-analysis. Many readers assumed that the sprightly title of his essay of 1932, 'How many Children had Lady Macbeth?', was a quotation from Bradley, but it was not; it was suggested by F. R. Leavis. In a later lecture, 'The Question of Character in Shakespeare' (published in 1959), Professor Knights modified his position and distinguished Bradley from his followers on the grounds that he 'had the great virtue of being thoroughly immersed in what he was talking about, and I am sure that his book has helped very many people to make Shakespeare a present fact in their lives'. By this time, his main criticism was that Bradley's attention to a text was too narrow, 'missing the critical "placing" determined by the play as a whole'. In Some Shakespearean Themes (1959), Professor Knights identified a whole series of 'probings, questionings, rejections, recognitions' which he believed could be traced in Shakespeare's writing of King Lear, and thereby he interpreted the tragedy in a more optimistic way than Bradley: 'For what takes place in King Lear we can find no other word than renewal.' But like Bradley, he sought a unifying vision and found that Lear himself was 'the centre of consciousness in the play'.

Shakespearean Tragedy is far more than a study of 'character' and the record of a search for unity in the plays, and most critics have come to recognize this. Wolfgang Clemen's influential The Development of Shakespeare's Imagery (1951) named Bradley among the earliest critics to study the 'metaphors and images' in the plays. Professor Clemen drew his own study of King Lear to a close by quoting Bradley's book alongside Caroline Spurgeon's Shakespeare's Imagery (1935) and Wilson Knight's The Wheel of Fire (1930): all four critics described the play in similar terms, but Bradley was the earliest 
of them by almost thirty years. Maynard Mack's 'King Lear' in Our Time (1965) makes use of Bradley's account of the structure of the tragedies, declaring that 'no one has succeeded in arguing away' his long list of improbabilities in this play. Earlier Professor Mack had written that Bradley's is 'still the best account we have of the outward shape' of the four major tragedies (Stratford-upon-Avon Studies, 1960). Kenneth Muir's Shakespeare's Tragic Sequence (1971) draws on the author's experience of editing both Lear and Macbeth for the new Arden Shakespeare and on his knowledge of 'many studies written during the last two decades', and yet here, among many voices, Bradley is this author's most constant companion and counsel. Professor Muir quotes his judgments again and again - when accounting for the structure of King Lear and trying to discover the meaning of the king's last words, or when considering the motives of Macbeth, or when contrasting Dr Leavis's theories about Othello's self-dramatization with opinions of Pushkin, Dostoevsky and Coleridge. It seems that Bradley had never dropped out of critical reckoning.

The continued influence of Shakespearean Tragedy is widespread, and two very different books from the 1980s can exemplify this. John Bayley's Shakespeare and Tragedy (1981) has greater show of confidence, moment by moment, than Bradley's book, so that its tone is very different; but both studies agree in giving primacy to Shakespeare's exploration of human consciousness:

with Shakespeare the mere fact and story of consciousness replaces both action and idea. It is the imminence of action which brings that consciousness into prominence, but it remains independent of action. ... The usurpation by the mind of both practical action and purposeful idea in tragedy . . . is the most important feature of Shakespeare's relations with the tragic form.

The difference between the two is most stark in that Professor Bayley denies the plays' heroes any greatness of achieve- 
ment because they are 'in one way or another ... unsuited to the action, its conventions, its atmosphere'. This is clearest in his study of King Lear:

the leading characters are not suited to play in a drama at all: as I suggested, they are, in their various ways, too boring to do so, too boring to be effectively taken over by actors. Lear himself belongs to that class of person whom it is not interesting to read about, and to hear, see, or talk to. A moment arrives in the play when everything he says is tedious in itself. . . .

Stephen Booth's 'King Lear', 'Macbeth', Indefinition, and Tragedy (1983) betrays in its cumbersome title an interest in mystery, discovery, and in the exterior experience of viewing a tragedy, step by step. Professor Booth's attentive scepticism is closer to Bradley than Professor Bayley's confidence; in finding a mystery in King Lear, he writes almost in the same vein:

Although I insist that Lear learns nothing in the course of the play and that King Lear has nothing to teach us, I also insist that the sense that Lear learns and that the play illuminates is of the play - is generated by King Lear, not foisted upon it by the benignly creative commentators who insist on telling us what Lear learns and what the great human truths are that King Lear so evidently makes evident. The fact that we find Lear 'meaningful' leads us to try to identify the meanings that fill it. The fact that we cannot find the meaning or meanings we seek does not, however, deny the fact that sends us questing: King Lear feels profoundly illuminating. . . . An audience to King Lear does not see the light but knows itself to be where light is.

That debate, which Bradley conducted in his Shakespearean Tragedy, he helped to fuel for others, and for many more 
decades. Perhaps his most lasting achievement was to show how rewarding such an engagement can be.

In an Introduction to the second volume of his collected Plays (1978), Edward Bond complained:

Recently I spoke to a man whose job it was to teach the meaning of Shakespeare's writings to students at a university. He told me Shakespeare had no opinions of his own, he could understand and retail everyone's opinion, he left it to others to judge.

From this dramatist's point of view, that sounded like nonsense:

Had Shakespeare not spent his creative life desperately struggling to reconcile problems that obsessed him he could not have written with such intellectual strength and passionate beauty.

Bradley would have answered in much the same way. Few books of criticism give us the sensation of being close to a creative mind, but Shakespearean Tragedy is a necessary masterpiece because it does just that. It can both widen and sharpen our view of the issues implicit in the tragedies, and deepen our understanding of Shakespeare's art. 


\section{INTRODUCTION}

In these lectures I propose to consider the four principal tragedies of Shakespeare from a single point of view. Nothing will be said of Shakespeare's place in the history either of English literature or of the drama in general. No attempt will be made to compare him with other writers. I shall leave untouched, or merely glanced at, questions regarding his life and character, the development of his genius and art, the genuineness, sources, texts, inter-relations of his various works. Even what may be called, in a restricted sense, the 'poetry' of the four tragedies - the beauties of style, diction, versification - I shall pass by in silence. Our one object will be what, again in a restricted sense, may be called dramatic appreciation; to increase our understanding and enjoyment of these works as dramas; to learn to apprehend the action and some of the personages of each with a somewhat greater truth and intensity, so that they may assume in our imaginations a shape a little less unlike the shape they wore in the imagination of their creator. For this end all those studies that were mentioned just now, of literary history and the like, are useful and even in various degrees necessary. But an overt pursuit of them is not necessary here, nor is any one of them so indispensable to our object as that close familiarity with the plays, that native strength and justice of perception, and that habit of reading with an eager mind, which make many an unscholarly lover of Shakespeare a far better critic than many a Shakespeare scholar.

Such lovers read a play more or less as if they were actors who had to study all the parts. They do not need, of course, to imagine whereabouts the persons are to stand, or what gestures they ought to use; but they want to realise fully and exactly the inner movements which produced these words and no other, these deeds and no other, at each particular moment. This, carried through a drama, is the right way to read the dramatist Shakespeare; and the prime requisite here is therefore a vivid and intent imagination. But this alone will hardly suffice. It is necessary also, especially to a 
true conception of the whole, to compare, to analyse, to dissect. And such readers often shrink from this task, which seems to them prosaic or even a desecration. They misunderstand, I believe. They would not shrink if they remembered two things. In the first place, in this process of comparison and analysis, it is not requisite, it is on the contrary ruinous, to set imagination aside and to substitute some supposed 'cold reason'; and it is only want of practice that makes the concurrent use of analysis and of poetic perception difficult or irksome. And, in the second place, these dissecting processes, though they are also imaginative, are still, and are meant to be, nothing but means to an end. When they have finished their work (it can only be finished for the time) they give place to the end, which is that same imaginative reading or re-creation of the drama from which they set out, but a reading now enriched by the products of analysis, and therefore far more adequate and enjoyable.

This, at any rate, is the faith in the strength of which I venture, with merely personal misgivings, on the path of analytic interpretation. And so, before coming to the first of the four tragedies, I propose to discuss some preliminary matters which concern them all. Though each is individual through and through, they have, in a sense, one and the same substance; for in all of them Shakespeare represents the tragic aspect of life, the tragic fact. They have, again, up to a certain point, a common form or structure. This substance and this structure, which would be found to distinguish them, for example, from Greek tragedies, may, to diminish repetition, be considered once for all; and in considering them we shall also be able to observe characteristic differences among the four plays. And to this may be added the little that it seems necessary to premise on the position of these dramas in Shakespeare's literary career.

Much that is said on our main preliminary subjects will naturally hold good, within certain limits, of other dramas of Shakespeare beside Hamlet, Othello, King Lear, and Macbeth. But it will often apply to these other works only in part, and to some of them more fully than to others. Romeo and Juliet, for instance, is a pure tragedy, but it is an early work, and in 
some respects an immature one. Richard III and Richard II, Julius Caesar, Antony and Cleopatra, and Coriolanus are tragic histories or historical tragedies, in which Shakespeare acknowledged in practice a certain obligation to follow his authority, even when that authority offered him an undramatic material. Probably he himself would have met some criticisms to which these plays are open by appealing to their historical character, and by denying that such works are to be judged by the standard of pure tragedy. In any case, most of these plays, perhaps all, do show, as a matter of fact, considerable deviations from that standard; and, therefore, what is said of the pure tragedies must be applied to them with qualifications which I shall often take for granted without mention. There remain Titus Andronicus and Timon of Athens. The former I shall leave out of account, because, even if Shakespeare wrote the whole of it, he did so before he had either a style of his own or any characteristic tragic conception. Timon stands on a different footing. Parts of it are unquestionably Shakespeare's, and they will be referred to in one of the later lectures. But much of the writing is evidently not his, and as it seems probable that the conception and construction of the whole tragedy should also be attributed to some other writer, I shall omit this work too from our preliminary discussions. 